against those who demand all the amenities that flow from applied science and yet denigrate their source. For now nuclear fission seems the only long term source of energy on the required scale; but should we not be pressing ahead more actively with the peaceful development of nuclear fusion, which does not release radioactivity into the environment?

Douglas BLACK

Chairman of the Independent Advisory Group

on Cancer in West Cumbria,

Whitchurch-on-Thames RG8 7EN

1 Independent Advisory Group. Investigation of the possible increased incidence of cancer in west Cumbria. London: HMSO, 1984.

2 Committee on Medical Aspects of Radiation in the Environment (COMARE). First report. London: HMSO, 1986.

\section{Chlormethiazole and alcohol: a lethal cocktail}

"Prescription for death" and "Deadly potion" ran the banner headlines in a recent edition of a south coast newspaper. ${ }^{12}$ The articles claimed that local general practitioners were unwittingly feeding a black market in chlormethiazole (Heminevrin) among alcoholics and that the practice had resulted in several deaths. This is not the first time that the risks of chlormethiazole abuse have gained prominence in the media. $^{3}$

The hypnotic, anxiolytic, and anticonvulsant properties of chlormethiazole ${ }^{4}$ make it an attractive choice for treating the excitatory state that characterises withdrawal from alcohol. ${ }^{5}$ In a rapidly reducing dosage regimen over six days chlormethiazole is highly effective ${ }^{6}$ and is now the most popular drug for alcohol withdrawal in Britain. ${ }^{7}$ If the drug is used long term, however, alcoholics readily transfer dependency to it $^{68-10}$ and may visit several general practitioners ${ }^{8}$ or hospitals ${ }^{11}$ in a short time to obtain supplies. Often alcohol abuse continues, ${ }^{12}{ }^{13}$ provoking an adaptation of the central nervous system that increases the dose of chlormethiazole needed to produce the desired effect. ${ }^{12}{ }^{14}$ Such cross tolerance may explain why some alcoholics take more than $25 \mathrm{~g}$ daily. ${ }^{8}$

Especially if drinking continues, the outcome of chlormethiazole abuse is often serious self poisoning with deep coma and centrally mediated respiratory depression that may kill. ${ }^{12}$ Alcohol increases the bioavailability of chlormethiazole, ${ }^{15} 16$ probably by impairing its normally extensive first pass hepatic metabolism..$^{17-20}$ In patients with alcoholic cirrhosis systemic bioavailability may be increased tenfold ${ }^{20}$ mainly because of extrahepatic and intrahepatic venous shunting. ${ }^{21}$ Nevertheless, direct additive pharmacological effects and enhanced cerebral sensitivity to chlormethiazole are probably much more important than kinetic interactions. ${ }^{21}$

All sedatives and hypnotics effective in treating alcohol withdrawal, including the benzodiazepines, share the dangers of tolerance, dependency, and potentially lethal interactions with alcohol..$^{51722}$ The particular association of chlormethiazole with these problems may reflect its popularity. A recent survey suggested that half the alcoholics requiring detoxification in Britain are managed at home by general practitioners who favour chlormethiazole and are prepared to continue its prescription long term. ${ }^{23}$ Such an approach is in sharp conflict with the warnings of the hazards of prolonged chlormethiazole treatment for ambulant alcoholics in published reports ${ }^{891213}$ and from the manufacturers. ${ }^{24}$

General practitioners who start outpatient detoxification must be prepared to provide close supervision. Issuing prescriptions for only one day's supply at a time should ensure daily contact and minimise but not abolish the potential for abuse. ${ }^{12} 22$ If the patient shows any evidence of tolerance to or dependency on chlormethiazole or of continuing to drink alcohol the only safe policy is rapid admission for inpatient care.

GORDON T MCINNES

Senior Lecturer,

University Department of Medicine,

Gardiner Institute,

Western Infirmary,

Glasgow G11 6NT

1 Bailey J. Prescription for death. Southern Evening Echo 1986 Nov 12:1

2 Bailey J. Deadly potion. Southern Evening Echo 1986 Nov 12:3.

3 Anonymous. Doctor warns of madness drug. Daily Record 1979 May 3:31 (col 1)

4 Evans JG, Feuerlein W, Glatt MM, Kanowski S, Scott DB, eds. Chlormethiazole 25 years: recent developments and historical perspectives. Acta Psychiatr Scand 1986;73 (suppl 329):1-198.

5 Rosenbloom AJ. Optimising drug treatment of alcohol withdrawal. Am $\mathcal{F}$ Med 1986;81:901-4.

6 Glatt MM, George HR, Frisch EP. Controlled trial of chlormethiazole in treatment of the alcoholic withdrawal phase. BrMed F 1965;ii:401-4.

7 Anonymous. Management of alcohol withdrawal symptoms. [Editorial.] Br Med $\mathcal{J} 1981 ; 282.502$.

8 Foster A. Sedatives for alcoholics. BrMed J 1977;i:1355.

9 Hession MA, Verma S, Bhakta KGM. Dependence on chlormethiazole and effects of its withdrawal. Lancet 1979; i:953-4.

10 Lundquist G. The clinical use of chlormethiazole. Acta Psychiatr Scand 1966;42 (suppl 192):113-4.

11 Cushnie JM, Ben-Tovim DI, Kopelman P. Chlormethiazole addiction: unusual presentation. BrMed f 1978;ii:355.

12 Horder JM. Fatal chlormethiazole poisoning in chronic alcoholics. Br Med f 1978;i:693-4.

13 Illingworth RN, Stewart MJ, Jarvie DR. Severe poisoning with chlormethiazole. Br Med $\mathcal{J}$ 1979;ii:902-3.

14 Kalant H, Khanna JM, Llewellyn M, Rinkel GJE, Woodworth I. Functional tolerance to chlormethiazole and cross-tolerance to ethanol in the rat: importance of test and mode of drug administration. Acta Psychiatr Scand 1986;73 (suppl 329):54-65.

15 Neuvonen PJ, Pentikäinen PJ, Jostell KG, Syvälahti E. The pharmacokinetics of chlormethiazole in healthy subjects as affected by ethanol. Clin Pharmacol Ther 1981;29:268-9.

16 Zysset T, Bircher J. Preferential reduction of first-pass elimination by ethanol. Model experiment with chlormethiazole in the rabbit. F Pharmacol Exp Ther 1981;217:198-203.

17 Linnoila M, Mattila MJ, Kitchell BS. Drug interactions with alcohol. Drugs 1979;18:299-311.

18 Moore RG, Triggs EJ, Shanks CA, Thomas J. Pharmacokinetics of chlormethiazole in humans. Eur f Clin Pharmacol 1975;8:353-7.

19 Nation RL, Vine J, Triggs EJ, Learoyd B. Plasma levels of chlormethiazole and two metabolites after oral administration to young and aged human subjects. Eur 7 Clin Pharmacol 1977;12:137-45.

20 Pentikäinen PJ, Neuvonen PJ, Tarpila S, Syvälahti E. Effect of cirrhosis of the liver on the pharmacokinetics of chlormethiazole. BrMed f 1978;ii:861-3.

21 Hoyumpa AM, Schenker S. Major drug interactions: effect of liver disease, alcohol and malnutrition. Annu Rev Med 1982;33:113-49.

22 Solomon F, White CC, Parron DL, Mendelson WB. Special report-sleeping pills, insomnia and medical practice. N Engl f Med 1979;300:803-8.

23 Stockwell T, Bolt E, Hooper J: Detoxification from alcohol at home managed by general practitioners. BrMed J 1986;292:733-5.

24 Association of the British Pharmaceutical Industry. Data sheet compendium 1986-87. London: ABPI, 1986:102-4.

\section{Stopping bleeding by embolisation}

Bleeding can usually be managed conservatively, but sometimes an operation may be necessary. Often those patients who do need an operation are old or ill; sometimes they have already had one operation. These sorts of patients may be candidates for transcatheter embolisation of their bleeding point, particularly as angiography will often be necessary to localise that point. ${ }^{1}$

Few parts of the body are inaccessible to modern catheter techniques, which are all performed under local anaesthesia. Once a bleeding site has been located (and it is usually surprisingly small) a catheter is manipulated as near as possible to it so that embolisation can be carried out. Many different materials are used as the embolus and many occlusion techniques are available, ${ }^{1}$ but the materials most 
commonly used are gelfoam, polyvinyl alcohol (foam), and steel coils.

If the patient is not fit for surgery embolisation of the coeliac axis is an effective treatment for severe bleeding in the stomach or duodenum localised by endoscopic examination. ${ }^{2}$ A good collateral blood supply makes occlusion of a single branch of the coeliac axis safe. If, however, findings on endoscopy are normal then superior and inferior mesenteric angiography is indicated for localisation. Infusion of intraarterial vasopressin is sometimes effective in controlling this bleeding, but embolisation has been little used because of the risk of ischaemic bowel complications. ${ }^{3}$ In occasional extreme circumstances it has, however, been used safely. ${ }^{45}$

Bleeding into the liver is often associated with haemobilia and may occur after trauma, an operation, and needling procedures as well as in various liver diseases. If after angiography the abnormal branch can be selectively catheterised then embolisation offers effective control. ${ }^{6}$ Oesophageal varices that are bleeding severely are a serious problem, and some centres have advocated portal vein catheterisation and embolisation when other treatments have failed. ${ }^{7}$ Severe bleeding may rarely occur from pancreatic lesions, and these can be effectively embolised provided the right arterial branch is adequately cannulated. ${ }^{28}$ Haemorrhage from the spleen is usually caused by traumatic rupture, and splenectomy is often necessary. Embolisation has been little used in the spleen, but it might be better as the spleen and its important immunological functions would be retained.

Severe bleeding from the kidney most commonly occurs in extensive malignant disease but may occur after an operation, trauma, and biopsy or other percutaneous procedures. Embolisation of selective branches will infarct only a small portion of the kidney and will often avoid a nephrectomy. ${ }^{9}$ Extensive bladder carcinoma and gynaecological malignancies may give rise to severe and persistent bleeding, and embolisation of the internal iliac artery or its branches can have a dramatic even though only palliative effect. ${ }^{810}$

Embolisation is an effective treatment for severe haemoptysis in cystic fibrosis or other chronic inflammatory lung diseases. ${ }^{11}$ In such cases the bleeding often recurs, but embolisation can be repeated with no further problems. Embolisation can sometimes be an effective treatment of severe and persistent bleeding in other parts of the body but particularly in the pelvis after trauma or an operation. ${ }^{812}$ Bleeding in some sites-such as the nose-may be catastrophic, and occasionally epistaxis is so severe that embolisation is considered as an alternative to an operation. ${ }^{13}$

The success and safety of embolisation depends on the skills and techniques of the interventional radiologist. Serious complications may result if adjacent structures or organs are inadvertently embolised. ${ }^{1}$ If radiology departments are to offer an embolisation service then staff must be prepared to offer a 24 hour emergency service. At present this requirement causes real problems and such a service is at best patchy. When angiography and embolisation are available there will be many circumstances when they will be the first choice for managing severe bleeding.

J F REIDY

Consultant Radiologist,

Guy's Hospital,

London SE1 9RT

1 Athanasoulis CA, Pfister RC, Greene RE, Robertson GH. Interventional radiology. Philadelphia: Saunders, 1982.

2 Feldman L, Greenfield AJ, Waltman AC, et al. Transcatheter vessel occlusion. Angiographic results versus clinical success. Radiology 1983;147:1-5.
3 Rosenkrantz H, Bookstein JJ, Rosen RJ, Guff WB, Healy JF. Post-embolic colonic infarction. Radiology 1982;142:47-51.

4 Palmaz JC, Walter JF, Cho KJ. Therapeutic embolization of small bowel arteries. Radiology 1984;152:377-82.

5 Chalmers AG, Robinson PJ, Chapman AH. Embolization in small bowel haemorrhage. Clin Radiol 1986;37:379-81.

6 Wagner WH, Lundell CJ, Donovan AJ. Percutaneous angiographic embolization for hepatic arterial hemorrhage. Arch Surg 1985;120:1241-9.

7 Johnson WC, Nabseth DC, Widrich WC, Bush HL, O'Hara ET, Robbins AH. Bleeding esophageal varices. Ann Surg 1982;195:393-400.

8 Jander HP, Russinovich AE. Transcatheter gelfoam embolization in abdominal, retroperitoneal and pelvic haemorrhage. Radiology 1980;136:337-44.

9 Lieberman SF, Keller FS, Pearse HD. Percutaneous vaso-occlusion for non-malignant renal Lieberman SF, Keller FS, Pearse
lesions. F Urol 1983;129:805-9.

10 Rosenthal PM, Colapinto R. Angiographic arterial embolization in the manaagement of postoperative vaginal hemorrhage. Am $\mathcal{f}$ Obstet Gynecol 1985;151:227-31.

11 Remy J, Lemaitre L, Lafitte JJ, Vilain MO, Saint Michael J, Steenhouwer F. Massive haemoptysis of pulmonary arterial origin: diagnosis and treatment. $A \not R$ 1984;143:963-9.

12 Miller ME, Niemann KMW, Meyer RD, Vitek J. Artériographic embolization for control of excess blood loss complication revision of total hip arthroplasty: a case report. $\mathcal{J}$ Bone foint Surg 1983;65:648-50.

13 Van Wyck LG, Vinuela F, Heeneman H. Therapeutic embolization for severe epistaxis. f Otolaryngol 1982;11:271-4.

\section{Pancreatic endocrine tumours}

The rapid advance in our knowledge of pancreatic endocrine tumours must have left confused non-specialists struggling in its wake. Thirty years ago the picture was refreshingly simple. In his second edition of the classic Companion in Surgical Studies Aird wrote on insulinomas in the section devoted to tumours of the islet cells. ${ }^{1}$ A small paragraph acknowledged that the pancreas might also contain inactive islet tumours, and a sentence mentioned (incorrectly) that $\alpha$ cell tumours of the islets might be associated with recurrent peptic ulceration. As a single author of an encyclopaedic book Aird can be forgiven for not discussing at length the seminal paper published two years earlier by Zollinger and Ellison which suggested a direct relation between non- $\beta$ islet cell tumours and peptic ulceration. ${ }^{2}$ Since then technological advances-notably electron microscopy, radioimmunoassay, and immunohistochemistry - have opened up the subject. So much so that our struggling non-specialist has been besieged by a plethora of novel endocrine and paracrine cells, has puzzled over putative new hormones without any apparent role, and has striven to remember the meaning of the acronym APUD (amine precursor uptake and decarboxylation) and its importance as a cytochemical means of linking together cells of a diffuse neuroendocrine system responsible for controlling digestion and carbohydrate metabolism.

Where are we now? There appear to be five types of islet cell normally present in the adult pancreas, each of which produces a distinct polypeptide or amine ${ }^{3}: \alpha$ cells produce glucagon, $\beta$ cells insulin, $\Delta$ cells somatostatin, $F$ cells (alternatively known as D2 or PP cells) pancreatic polypeptide, and enterochromaffin cells serotonin. Tumours may arise from each of the cell types, but, whereas glucagonomas, insulinomas, and carcinoid tumours usually give rise to functional upset, those that produce somatostatin or pancreatic polypeptide may be clinically silent. Unfortunately, the problem is complicated by pancreatic endocrine tumours also developing from cell types not normally resident in the adult pancreas. Such ectopically functioning tumours include those that produce gastrin (gastrinoma) or vasoactive intestinal peptide (vipoma), and even rarer forms may produce corticotrophin and polypeptides with activity like that of parathormone. These ectopically functioning tumours often produce more than one polypeptide, giving rise to a bizarre clinical picture; and in general they have a 